
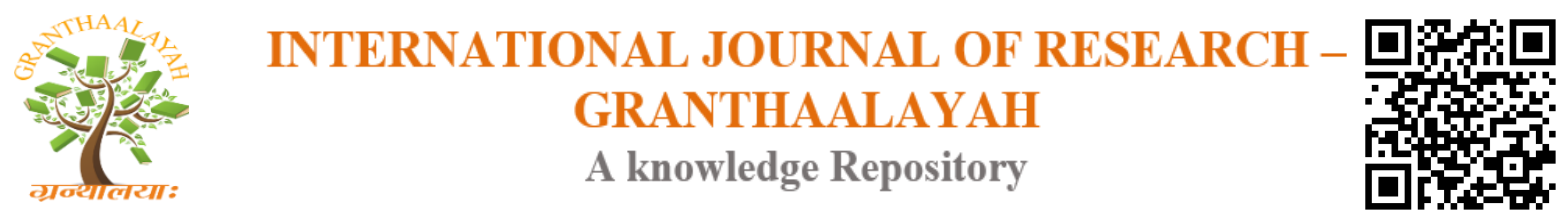

Science

\title{
A CRITICAL REVIEW: TAMAKA SHWASA (BRONCHIAL ASTHMA)
}

\author{
Dr Vaishnavi Narhari Saka *1 \\ ${ }^{* 1}$ MD Scholar, Kayachikitsa department, S.G.R. Ayurved Mahavidyalaya, Solapur, Maharashtra, \\ India
}

\begin{abstract}
Out of most morbid disorders, the disease shwas is also becoming a major health problem of the society. Difficulties in breathing, cough are common health complains which everyone experiences throughout their life with different magnitude. Such complains are found in every age group. Dyspnea due to respiratory diseases comes under ShwasaRoga. Maha- Urdhva-ChinnaTamaka and Kshudra are the types of ShwasaRoga. Bronchial asthma is a chronic inflammatory disease of airways characterized by cough, difficulty in breathing and wheeze. Exposure to dust, smoke, recurrent respiratory infections and climatic changes are chief triggering factors of this disease. Bronchial asthma and its associated features clinically correspond to the Tamaka Shwasa described in Ayurveda.
\end{abstract}

Keywords: Bronchial Asthma; Nocturnal Asthma; Shwasaroga and Tamakashwasa.

Cite This Article: Dr Vaishnavi Narhari Saka. (2019). "A CRITICAL REVIEW: TAMAKA SHWASA (BRONCHIAL ASTHMA)." International Journal of Research - Granthaalayah, 7(8), 258-264. https://doi.org/10.29121/granthaalayah.v7.i8.2019.667.

\section{Introduction}

Ayurveda deals with preventive, promotive as well as curative aspects. Ayurveda is a science of life and longevity. Over the past few years, our lifestyle has changed and we often tend to ignore the importance of healthy living in one way or the other. The main causes behind poor health conditions are diseases, improper diet, injury, mental stress, lack of hygiene, unhealthy lifestyle, etc. Physical, mental and spiritual wellbeing is the appropriate meaning of health in true sense. Proper breathing is essential for good health. Breathing brings both oxygen and the vitality to every cell in the body. Shortness of breath, cough are those common health complains which everyone experience throughout their life with different magnitude. Such complains are found in every age group. In Ayurvedic text, the clinical entity described with cardinal feature of difficulty in breathing is ShwasaRoga. There are five types of ShwasaRoga described in Ayurveda. Tamakashwasa is one of the types of ShwasaRoga. 


\section{Disease Review}

\section{ShwasaRoga}

It is characterized by pathological changes in the respiratory system and thus causing labored breathing or difficulty in breathing. Difficulty in breathing or labored breathing is explained by the term Bhastrikadhmanasame which means the chest moves like bellows of blacksmith threatening the course of life ${ }^{1}$. Acharya Sushruta described that normal Prana Vayu gets vitiated and its movement is obstructed by Kapha. This leads to increased and labored breathing, results in Shwasa Roga ${ }^{2}$. Normally, Prana Vayu governs the process of breathing. It provides life, nourishment and also performs Jatharagni Deepana ${ }^{3}$. It may be the reason that patients of shwasaroga usually suffers from Agni disorder. The causative factors of shwasaroga are described as raja-dhumavata-shitasthana-shitaambu-Vyayama. It is evident that difficulty in breathing occurs or triggered on exposure to dust, smoke, wind, after intake of cold water or other items and after doing exercise. Ama Pradosha is also considered as causative factors for shwasa roga ${ }^{5}$. The prodomal features of shwasaroga are Anaha (Abdominal distension), Parsvashoola(pain in costal region), Hridayapida (pericardial pain) and Pranasya Vilomatvama. Acharya Chakrapani has explained the term Pranasya Vilomatvama as Pranasya Paryakulatvam which means disorder of life or breathing ${ }^{6}$. The specific pathogenesis of Shwasa Roga is described as exposure to etiological factors leads to vitiation of Kapha along with Vata which causes obstruction of Pranavaha Srotas. This generates movement of vayu in all direction in Pranavaha Srotas and body, ultimately causes Shwasa roga. Acharya Vaghbhata added involvement of Udakavaha and Annavaha Srotasa along with Pranavaha in the Samprapti(pathogenesis) of Shwasa Roga $a^{8}$ In the pathogenesis of Shwasa Roga, consideration of these Srotas can be coherantly understood by observing Moola of these Srotas. Moola(root) of UdakavahaSrotas is Talu and Kloma ${ }^{9}$. Talu is palate ${ }^{10}$ and kloma is tracheal tree and attached lungs ${ }^{11}$, which are important parts of respiratory system. Ama is also said to be the causative factor of UdakavahaSrotoDusti ${ }^{12}$, similar to Shwasaroga. Annavahasrotas have Amashaya and VamaParshva as its Moola ${ }^{13}$. Amashaya ${ }^{14}$ is the main site of Pitta Dosha and Shwasa Roga is also said to have its origin from Pitta Sthana ${ }^{15}$. Shwasa Roga is chiefly caused by Vata and Kapha Dosha but the site of origin of this disease is Pitta Sthana ${ }^{15}$. Five types of Shwasa Roga are MahaShwasa, UrdhvaShwasa, ChinnaShwasa, TamakaShwasa and KshudraShwasa ${ }^{16}$.Among these, MahaShwasa, UrdhvaShwasa and ChinnaShwasa are Asadhya (incurable) whereas KshudraShwasa is not that much annoying ${ }^{17}$. TamakaShwasa is a yapya disorder ${ }^{18}$. Thus, it is difficult to cure and prevention of the causative factors as well as treatment is needed throughout the life.

\section{TamakaShwasa}

Tamakashwasa consists of two words viz Tamaka and shwasa. 'Tama' means darkness or to choke $^{19}$. There is no separate description for prodomol features of TamakaShwasa but distinguished pathogenesis has been described. Aggravated vata due to exposure to causative factors leads to its Pratilomagati or reverse movement Vitiated vata runs through channels and reaches head - neck region. It exaggerates the regional Kapha by increasing epithelial secretion and produce pinasa. These secretions or malarupikapha obstructs the passage of air and produces ghurgur shabda or wheezing sound ${ }^{20}$.

Clinical Features of Tamaka Shwasa ${ }^{20}$ 
1) Pinasa - Vitiation of Vata due to obstruction in Pranavaha Srotas due to Kapha causes pratilomagati of vayu along with kapha and produces Pinasa.

2) Griva - Sirasa Sangraha - Vitiated Vata causes spasm and rigidity of neck muscles. It causes stiffness of neck and restricts movement of neck and head.

3) Ghurghurkamashabda - Ghurghur shabda or wheezing is abnormal sound during breathing. Due to obstruction of srotas by kapha, vitiated udanavayu results in ghurghur shabda. Narrowing of srotas due to vitiated prana and vyana also results in wheezing sound.

4) Pramoha - Persistence of compromised blood supply to the organs results in slow heart rate and fall in blood pressure. This results in failure of peripheral blood circulation and ultimately causing fainting and shock.

5) Kanthodhwansa - Madhukosa commentary on Madhav Nidana interpreted Kanthodhwansa as "itching in kantha" which can be due to repeated attacks of cough and vitiated Kapha.

6) Parshvasgraha - It is due to fatigue of respiratory muscles resulted from increased breathing and repeated cough.

7) Ushnamabhinandte - Predominant doshas in Tamakashwasa are vata and kapha having 'Shita' as their guna. Use of ushnaguna through hot drinks, food and atmostphere does kapha-vilayana and vata-anulomana. Thus, this causes relief in symptoms of TamakaShwasa.

8) Meghambu shita Pragvatah Shleshma chabhivardhate - These are triggering factor mainly vitiates vata and kapha doshas and provoke the pathology of disease.

9) Lalatasweda - It is seen in acute exacerbation of asthma when patient is exhausted due to rapid breathing. Lalatasweda signifies sweating due to exhaustion and rapid breathing.

10) Slesmanivimokshante Mahuratum Sukham - After expectoration patient feel better because of the sticky sputum is expectorated and the frequency of cough is reduced and easy ventilation is facilitated for a short time.

11) Vishushkashyate - Oral breathing in the condition of Pinasa can lead to dryness of mouth.

12) Muhur Shwasa - In patients of Tamakashwasa, to compensate decreasing oxygen level in blood, the respiratory rate in patient increases and results in rapid breathing.

13) MuhushchivaAvadhamyate - The body moves along with respiration during attack. While during inspiration the trunk is raised and during expiration lowered. As per Madhukosa commentary, it is shaky movement of the body due to increased breathing and it looks as if patient is riding on an elephant.

14) BhrusumArtimana - During the attack of shwasa, patient experiences repeated episodes of cough and dyspnea. Therefore, he cannot breath properly and he is under great distress. In Ayurveda, two subtypes of TamakaShwasa have been described ${ }^{21}$.

- Pratamaka Shwasa - When Tamaka Shwasa is associated with symptoms like Jwara and Murcha, it is known as Pratamaka shwasa. It is caused by Udavarta, raja, ajirna, klinna kaya and suppression of natural urges. According to Madhukosha commentary, association of Pittadosha with vata and kapha causes pratamaka shwasa.

- Santamaka Shwasa - This subtype of Tamaka Shwasa increases during night time and is relieved by cold things. It is known as Santamaka Shwasa because the patient feels as if he 
is drowning in the darkness usually the attacks precipitate early in the morning. Acharya Chakrapani and Jejjata described only Pratamaka Shwasa as a subtype of Tamakashwasa and according to Madhukosha commentary; Pratamaka Shwasa is synonym of Santamaka Shwasa.

\section{Chikitsa of TamakaShwasa}

According to Acharya Charaka, any drug or dietary regime etc. which alleviates Kapha and Vata, have ushna property and promotes downward movement of vata, should be used in the patient of shwasaroga. Things which pacifies Kapha only but aggravates vata or things which pacifies vata but aggravates kapha should not be used in the treatment of Shwasaroga. Best among both of these is to use those drugs, medicines and dietary regime which alleviates vata but may aggravate kapha. Vatahara treatment is better than kaphahara treatment because vatahara treatment may aggravates kapha but it minimizes the complications associated with disease and also improves the prognosis, whereas kaphahara treatment pacifies kapha but also causes depletion of dhatu and produces serious side effects ${ }^{22}$.

Nidana Parivarjana - Avoidance of etiological, aggravating and triggering factors is Nidana parivarjana. If precautions are taken against causative factors, then initiation of pathology can be prevented. Exposure to dust and smoke, cold and rainy weather, intake of cold drinks and other cold food items, excessive exercise and other physical activity are some of the factors that should be avoided by patients of shwasaroga.

Snehana \& Swedana - Use of Swedana locally or throughout whole body helps in liquefaction of viscous malarupi Kapha and also does vata anulomana. Acharya Charaka specially indicated following type of swedana in the treatment of Hikka and Shwasa Nadisweda, Prastara sweda and Sankara sweda. Snehana karma prepares body for the shodhana karma. Acharya charaka indicated the use of Tila taila and Saidhava Lavana for the massage over chest region in the patients of shwasa roga ${ }^{23}$.

Vamana Karma - It should be the choice of treatment in Kapha predominant state of shwasaroga(Tamakashwasa) as it expels the stagnant Malarupi Kapha from the srotasa and normalize the movement of vata. After proper swedana, snigdhaodana (rice), with soup of fish or pig flesh and the supernatent of curd may be given to the patients for kapha utklesha. Thereafter, vamana should be performed with the help of Madanaphala pipali, mixed with saindhava and madhu (honey), taking care of to see that such anemetic is not antagonistic to vata $^{24}$.

- Virechana karma - The site of origin of Shwasaroga is Pitta sthana. Virechana karma is indicated as the best treatment for the aggravated Pitta dosha. Therfore, virechana helps in maintaining the normal levels of pittadosha. Although, Basti is the best treatment for vatadosha but Acharya Charaka has explained that if Vata is associated with other doshas, then mridu samshodhana or mridu virechana should be done with oilation25. So,Virechana karma also pacifies vata dosha which is associated with kapha in patients of Shwasaroga.

- Shamana chikitsa - Procedures like Vamana and Virechana cannot be done in old age patients, emaciated patients, patients suffering from other co-morbid conditions along with shwasaroga etc. In such cases, shaman chikitsa (treatment with medicines only) is the choice of treatment. 


\section{Bronchial Asthma}

Asthma is a syndrome characterized by airflow obstruction that varies markedly, both spontaneously and with treatment. Asthmatics harbor a special type of inflammation in the airways that makes them more responsive than non-asthmatics to awide range of triggers, leading to excessive narrowing with consequent reduced airflow and symptomatic wheezing and dyspnea. Narrowing of the airways is usually reversible, but in some patients with chronic asthma there may be an element of irreversible airflow obstruction ${ }^{26}$. Nocturnal asthma refers to asthma symptoms that seem worse in the middle of the night, typically between 2 AM and 4AM. Interestingly, nocturnal asthma can affect someone with any type of asthma. Factors that can cause your asthma symptoms to worsen at night may include sinus infections or postnasal drip caused by allergens such as dust mites or pet dander. The body makes adrenaline and corticosteroids, which protect against asthma. Levels of these two substances are lowest between midnight and 4AM, making it more likely to experience symptoms during these times ${ }^{27}$.

\section{Discussion}

It is evident that types of Shwasa Roga in Ayurveda have been described on observing the breathing pattern, pathological changes and clinical features. On this ground, Tamaka Shwasa can be nearly corresponds with Bronchial Asthma. Ghurghur shabda, Kanthodhwansa, Parshvashoola, Meghambushita Pragvatah Shleshmachabhivardhate, Slesmanivimokshante, MahuratumSukham and Vishushkashyate are cardinal features found in Bronchial asthma. Pinasa (coryza or allergic rhinitis) is usually found as an associated feature with Bronchial asthma. Clinical features like Pramoha, Lalatasweda, Muhuschiva Avadhamyate, Bhrusum Artiman are related to acute exacerbation of bronchial asthma. Pratamaka shwasa is triggered by environmental allergens and seasonal variation. On the basis of disease pattern, Pratamaka shwasa corresponds to allergic asthma with super added seasonal viral or bacterial infection Besides this, Santamaka Shwasa is said to be aggravated by tama or darkness or during night. It is evident that Santamaka Shwasa corresponds to Nocturnal asthma.

\section{Conclusion}

Dyspnea or difficulty in breathing due to respiratory diseases is related to Shwasa Roga. It is evident that Tamakashwasa is a disease of respiratory tract. Formation of Ama plays an important role in the pathology of Tamakashwasa. Along with Pranavaha Srotasa, Udakavaha and Annavaha Srotas are also involved in the pathogenesis of Tamaka Shwasa. On the clinical grounds, Tamaka Shwasa very much corresponds to a disease known as Bronchial Asthma. Clinical features and types of Tamakashwasa are similar to pattern and associated features found in Bronchial asthma.

\section{References}

[1] Tripathi Brahmananda, Madukosha commentary on Madhava Nidanam By Sri Madhavakara, Chapter 12, verse no.16, Varanasi, Chaukhambha Sanskrit Sansthan p. 384, Reprint 2007.

[2] Shastri AmbikaDutt commentary on Sushruta Samhita of Maharishi Sushruta, Uttarasthana, Chapter 51, verse no.4, Varanasi, Chaukhambha Sanskrit Sansthan p. 372, Reprint 2007. 
[3] Srivastava shailaja commentary on Sharngadhar samhita of Acharya Sharngadhar, Chapter 5, verse no.51, Varanasi, Chaukhambha Orientalia, p. 45, Reprint edition2009.

[4] Trikamji Yadavji Acharya, Agniveshakrita Charaka Samhita Chakrapani Commentary, Chikitsasthan, Chapter 17, Hikka Shwasa chikitsa, Verse no. 11, Varanasi, Chaukhambha Surbharti Prakashan, p. 533, Reprint 2011.

[5] Trikamji Yadavji Acharyav Agniveshakrita Charaka Samhita Chakrapani Commentary, Chikitsasthan, Chapter 17, Hikka Shwasa chikitsa, Verse no.12, Varanasi, Chaukhambha Surbharti Prakashan, p. 533, Reprint 2011.

[6] Trikamji Yadavji Acharya, Agniveshakrita Charaka Samhita Chakrapani Commentary, Chikitsasthan, Chapter 17, Hikka Shwasa chikitsa, Verse no. 20, Varanasi, Chaukhambha Surbharti Prakashan, p. 533, Reprint 2011.

[7] Trikamji Yadavji Acharya, Agniveshakrita Charaka Samhita Chakrapani Commentary, Chikitsasthan, Chapter 17, Hikka Shwasa chikitsa, Verse no. 45, Va ranasi, Chaukhambha Surbharti Prakashan, p. 535, Reprint 2011.

[8] Gupta Kaviraj Atrideva, Astanga Hridayam By Vagbhata, Nidanasthana, Chapter 4, Verse no. 3, Varanasi, Chaukhamba Prakashan p.315, Reprint 2009.

[9] Trikamji Yadavji Acharya, Agniveshakrita Charaka Samhita Chakrapani Commentary, Vimanasthana, Chapter 5, Srotaovimana, Verse no. 8, Varanasi, Chaukhambha Surbharti Prakashan, p. 250, Reprint 2011.

[10] Gaur Damodar Shastri, Abhinav Sharir, Ist part, Pratham Khanda, p- 165, Nagpur, Shree Baidyanath Ayurved Bhawan Ltd., 1982.

[11] Gaur Damodar Shastri, Abhinav Sharir, Ist part, Pratham Khanda, p- 171, Nagpur, Shree Baidyanath Ayurved Bhawan Ltd., 1982.

[12] Trikamji Yadavji Acharya, Agniveshakrita Charaka Samhita Chakrapani Commentary, Vimanasthan, Chapter 5, srotovimana, Verse no. 11, Varanasi, Chaukhambha Surbharti Prakashan, p. 251, Reprint 2011.

[13] Trikamji Yadavji Acharya, Agniveshakrita Charaka Samhita Chakrapani Commentary, Vimanasthan, Chapter 5, srotovimana, Verse no. 8, Varanasi, Chaukhambha Surbharti Prakashan, p. 250, Reprint 2011.

[14] Trikamji Yadavji Acharya, Agniveshakrita Charaka Samhita Chakrapani Commentary, sutrasthan, Chapter 20, maharogadhyaya, Verse no. 8, Varanasi, Chaukhambha Surbharti Prakashan, p. 113, Reprint 2011.

[15] Trikamji Yadavji Acharya, Agniveshakrita Charaka Samhita Chakrapani Commentary, Chikitsasthan, Chapter 17, Hikka Shwasa chikitsa, Verse no. 8, Varanasi, Chaukhambha Surbharti Prakashan, p. 533, Reprint 2011.

[16] Trikamji Yadavji Acharya, Agniveshakrita Charaka Samhita Chakrapani Commentary, Sutrasthan, Chapter 19, Ashtodariya adhyaya, Verse no. 4, Varanasi, Chaukhambha Surbharti Prakashan, p. 110, Reprint 2011.

[17] Trikamji Yadavji Acharya, Agniveshakrita Charaka Samhita Chakrapani Commentary, Chikit sasthan, Chapter 17, Hikka Shwasa chikitsa, Verse no. 65-67, Va ranasi, Chaukhambha Surbharti Prakashan, p. 536, Reprint 2011.

[18] Trikamji Yadavji Acharya, Agniveshakrita Charaka Samhita Chakrapani Commentary, Chikit sasthan, Chapter 17, Hikka Shwasa chikitsa, Verse no. 62, Varanasi, Chaukhambha Surbharti Prakashan, p. 535, Reprint 2011.

[19] Vaman Shivram Apte, The Practical Sanskrit-English Dictionary, Delhi, Motilal Banarasi Publishers Private Limited, Revised edition2004.

[20] Trikamji Yadavji Acharya, Agniveshakrita Charaka Samhita Chakrapani Commentary, Chikitsasthan, Chapter 17, Hikka Shwasa chikitsa, Verse no. 55-62, Varanasi, Chaukhambha Surbharti Prakashan, p. 535, Reprint 2011. 
[21] Trikamji Yadavji Acharya, Agniveshakrita Charaka Samhita Chakrapani Commentary, Chikitsasthan, Chapter 17, Hikka Shwasa chikitsa, Verse no. 63-64, Varanasi, Chaukhambha Surbharti Prakashan, p. 535, Reprint 2011.

[22] Trikamji Yadavji Acharya, Agniveshakrita Charaka Samhita Chakrapani Commentary, Chikitsasthan, Chapter 17, Hikka Shwasa chikitsa, Verse no. 147-157, Varanasi, Chaukhambha Surbharti Prakashan, p. 539, Reprint 2011.

[23] Trikamji Yadavji Acharya, Agniveshakrita Charaka Samhita Chakrapani Commentary, Chikitsasthan, Chapter 17, Hikka Shwasa chikitsa, Verse no. 71, Varanasi, Chaukhambha Surbharti Prakashan, p. 535, Reprint 2011.

[24] Trikamji Yadavji Acharya, Agniveshakrita Charaka Samhita Chakrapani Commentary, Chikitsasthan, Chapter 17, Hikka Shwasa chikitsa, Verse no. 72-74, Varanasi, Chaukhambha Surbharti Prakashan, p. 536, Reprint 2011.

[25] Trikamji Yadavji Acharya, Agniveshakrita Charaka Samhita Chakrapani Commentary, Chikitsasthan, Chapter 28, vatavyadhi chikitsa, Verse no. 86, Varanasi, Chaukhambha Surbharti Prakashan, p. 620, Reprint 2011.

[26] Harrison's Principle of Internal Medicine, McGraw Hill, 17th edition. http://www.lung.org/associations/states/colorado/asthma/Asthma.html

*Corresponding author.

E-mail address: drvaishnavisaka93@ gmail.com 